\title{
„Soft skills“ začínajících pedagogů aneb s jakými sociálními dovednostmi a osobnostními kvalitami odcházejí učitelé z pedagogických fakult do profesní reality
}

\author{
Social skills and personal qualities of the graduates of faculties of education
}

\author{
Petr Soják, Iva Navrátilová
}

\begin{abstract}
Anotace: Text se zaměřje na zmapování oblasti sociálních dovedností a osobnostních kvalit absolventů pedagogických fakult. Kvalitativní výzkumná část odhaluje prostřednictvím expertního šetření oblasti sociálních dovedností a osobnostních kvalit, které jsou podle odborníků pro budoucí učitele nepostradatelné. Kvantitativní část potom zjišt’uje, jak v těchto oblastech posuzují své sociální dovednosti a osobnostní kvality samotní budoucí učitelé a jaké faktory mají vliv na jejich posouzení.
\end{abstract}

Klíčová slova: sociální dovednosti, osobnostní kvality, sebeposouzení, pedagogická komunikace, psychická kondice, sebepojetí, classroom management, zvládání konfliktů, supervize

\begin{abstract}
The text maps the area of social skills and personal qualities of the graduates of faculties of education. Through the experimental investigation the qualitative part reveals social skills and personal qualities, which are according to the experts, essential for future teachers. The quantitative part then figures out how future teachers assess their social skills and personal qualities themselves in these areas and which factors influence their assessment.
\end{abstract}

Keywords: social skills, personal qualities, self-assessment, educational communication, mental condition, self concept, coping with conflicts, supervision

\section{1 Úvod}

Prvým předpokladem pro výkon profese pedagoga $\mathrm{v}$ současnosti by mělo být to, že je osobností zralou, ,prosociálně“ orientovanou, osobností bez neurotických a psychopatických rysů, s předpoklady sebereflexe vlastního rozhodování, jednání i emocí, otevřenou podnětům, ochotnou na sobě pracovat a procházet i jistými supervizemi (Kraus, 2000).

Inspirací ke sledování osobnostních kvalit a sociálních dovedností pedagogických pracovníků pro nás mimo jiné byl článek pana Valenty (2008), který je věnován učitelské profesi ve smyslu sociálních kompetencí. Valenta zde osobnost učitele a jeho počínání vymezuje jako nedílnou součást kurikula (resp. skrytého kurikula ${ }^{1}$ ). „Je to látka, s níž se žák setkává, sleduje ji a reaguje na ni. At' již v tom smyslu, že přebírá / osvojuje si její projevy, nebo se naopak učí hledat takové projevy, které by mu umožnily na tuto „látku“ reagovat (napr. jinak než ona „látka“" očekává, tedy třeba překvapit učitele; podvést učitele atd.)“"Valenta (2008, s. 49).

\footnotetext{
${ }^{1}$ Jde o nezáměrné, implicitní, nebo utajované kurikulum. Skryté kurikulum popisuje vlivy, které utvářejí žáky a studenty, naučí je tomu, co není školou zjišt'ováno a často ani zamýšleno (Průcha, Walterová, \& Mareš, 2009).
} 
Presentovaný výzkumný záměr se orientoval na budoucí učitele (resp. studenty v posledním ročníku učitelských programů pedagogických fakult) a také na odborníky, kteří je na jejich učitelskou dráhu připravují. Výchozím prvkem bylo expertní šetření realizované na čtyřech pedagogických fakultách v České republice. Toto šetření dalo základ pro teoretickou i empirickou část diplomové práce, kde je možné podrobněji sledovat získané výstupy.

\section{Cíle výzkumného záměru}

Cíle výzkumného záměru byly vymezeny na základě jednotlivých částí empirického šetření. První, kvalitativní, část výzkumu tvoř́ expertní šetření. Snažili jsme se zjistit, jakými sociálními dovednostmi a osobnostními kvalitami by měli být vybaveni budoucí učitelé dle osmi odborníků z pedagogických fakult, kteří je připravují na jejich budoucí profesi. Cílem nebylo postihnout komplexní představu o ideálním učiteli, šlo spíše o to pochopit dílčí dovednosti a kvality, bez kterých se učitel ve své praxi jen těžko obejde. Cílem druhé kvantitativní části výzkumu bylo zjistit, jak tyto zmíněné oblasti posuzují samotní budoucí učitelé, resp. studenti posledních ročníků pedagogických fakult učitelských oborů. Dále jsme se snažili odhalit, zda a př́padně jaké konkrétní souvislosti existují mezi posouzením vlastní vybavenosti v daných oblastech a jednotlivými faktory - pohlaví, univerzita, forma studia, studovaný obor.

\section{Metodologické postupy}

Z předešlého textu vyplývá, že pro naplnění podstaty výzkumu byl aplikován smíšený výzkum. Pro záměry kvalitativní části byla zvolena metoda polostrukturovaný rozhovor. Metoda expertních rozhovorů byla zvolena pro získání pohledu fundovaných odborníků na danou problematiku. Data získaná $\mathrm{z}$ analýzy sloužila k sestavení elektronického sebeposuzovacího dotazníku škálového typu, který byl stěžejní pro kvantitativní část výzkumu. Obsah dotazníku se skládal z šesti kategorií, které se vztahovaly k sociálním dovednostem a osobnostním kvalitám pedagogů. Každá kategorie pak obsahuje pět výroků, k nimž respondenti pomocí číselné škály vyjadřovali míru ztotožnění se s daným výrokem. Dotazovanými byli studenti posledních ročníků magisterských a navazujících magisterských studií učitelských oborů na čtyřech pedagogických fakultách.

\subsection{Kvalitativní část výzkumu}

Z analýzy dat získaných expertními rozhovory vzešly následující kategorie. Jednotlivé kategorie byly pro zpřehlednění dále rozděleny do subkategorií:

- Pedagogická komunikace a interakce (předávání informací; motivace; zpětná vazba; aktivita žáka a učitele),

- Psychická kondice učitele (práce versus soukromý život; emoční inteligence; zvládání stresových situací),

- Sebepojetí učitele (osobní připravenost; seberozvoj),

- Classroom management (práce se skupinou; vedení diskuse; udržení kázně/autorita učitele; time-management),

- Zvládání konfliktů (diagnostika konfliktní situace; konstruktivní řešení konfliktu)

- Supervize v pedagogickém prostředí (vnímání supervize). 
V následné kvantitativní části respondenti pomocí zmíněné škály vystihovali míru svého ztotožnění s výroky v jednotlivých oblastech - kategoriích.

\subsection{Kvantitativní část výzkumu}

V rámci složení výzkumného souboru byl u respondentů zohledňován faktor pohlaví, studované univerzity, formy studia a studovaného oboru. Vzhledem k zaměření celého výzkumu a tedy výběru výzkumného vzorku bylo možné očekávat jistou převahu ženského pohlaví mezi respondenty. Muži tedy tvořili pouhých 14,7 \% a ženy zbylých 85,3\%.

Z hlediska studované univerzity bylo složení výzkumného vzorku následující: Masarykova univerzita - 62,5 \%; Univerzita Karlova - 16,4 \%; Palackého univerzita - 13,4 \% a Univerzita Hradec Králové - 7,7\%.

Faktor formy studia pak respondenty rozdělil do skupin s následujícím zastoupením: Studium v prezenční formě - 72,8 \%; Studium v kombinované formě $-27,2 \%$.

$\mathrm{V}$ rámci studovaného oboru vznikly $\mathrm{z}$ výzkumného vzorku tyto skupiny respondentů: Učitelství pro 1. stupeň ZŠ - 32,8 \%; Učitelství pro 2. stupeň ZŠ - 14,7 \%; Učitelství pro SS̆ $-25 \%$; Specializace v pedagogice $-27,5 \%$.

\section{Výstupy z dotazníku}

Respondenti definovali své rozhodnutí, do jaké míry se ztotožňují s danými výroky, pomocí číselné škály, kde nejnižší hodnota „1“ znamenala nejnižší míru ztotožnění a hodnota „,6“ znamenala nejvyšší míru ztotožnění. Průměr škály lze tedy přisoudit hodnotě ,3,5“. Tyto hodnoty pak zároveň vypovídají o tom, jak respondenti posuzují své sociální dovednosti a osobnostní kvality v daných oblastech. U výroků s opačnou polaritou byla provedena inverze hodnot. Na základě výsledků jednotlivých kategorií byl stanoven aritmetický průměr všech hodnot získaných z dotazníkového šetření. Hodnota souhrnného aritmetického průměru byla stanovena na 4,152 .

Výsledky shrnující průměrné hodnoty jednotlivých kategorií naznačovali, že žádná z těchto průměrných hodnot se nevyskytovala pod průměrem posuzovací škály. Blíže k průměru škály inklinovaly zejména kategorie Zvládání konfliktů a Classroom management. Průměrně vyšší hodnoty v rámci posuzovací škály pak byly přisuzovány výrokủm v kategorii Pedagogická komunikace a Sebepojetí.

Z výsledků dále vyplývá, že se průměrné hodnoty pohybovaly spíše nad průměrem škály. U kategorií lze rovněž předpokládat podobný rozsah mezi minimálním a maximálním průměrem přisouzených hodnot (viz obrázek 1).

Pro potřeby testování byly zohledněny průměry jednotlivých naměřených hodnot, jež respondenti přiřazovali pomocí posuzovací škály. Faktory jsou v tomto př́padě reprezentovány pohlavím, univerzitou, studovaným oborem a formou studia. V př́padě faktoru univerzity, který rozdělil respondenty na čtyři skupiny dle studované univerzity, bylo výsledné zastoupení z Masarykovy univerzity výrazně vyšší než zastoupení jiných univerzit. $\mathrm{Z}$ tohoto důvodu byly zbylé tři univerzity sloučeny a faktor tedy dále dělil respondenty do dvou skupin (Masarykova univerzita; ostatní univerzity). 


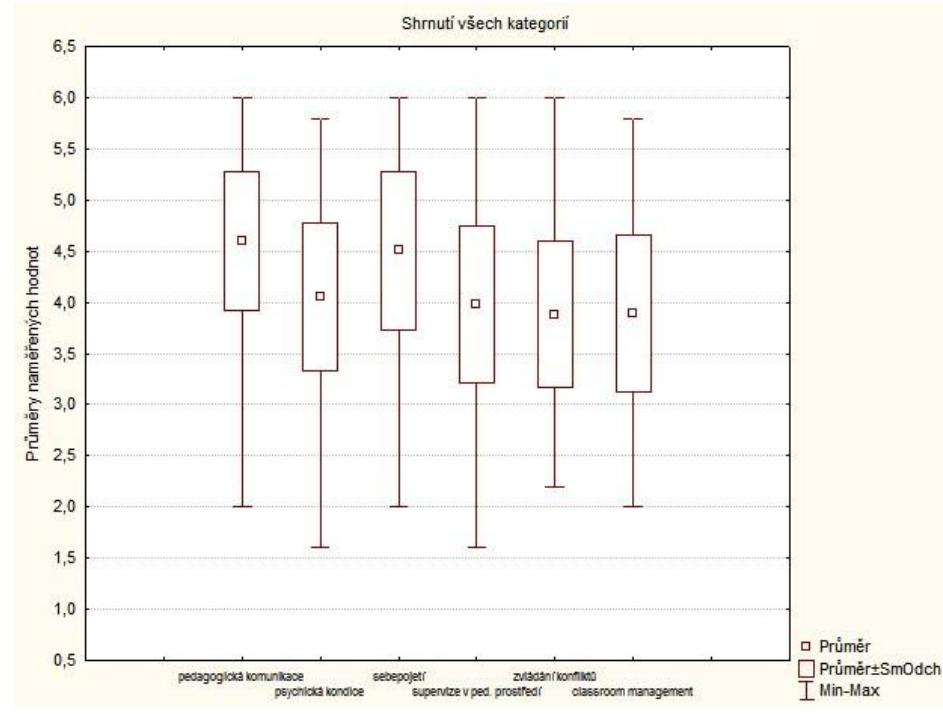

Obrázek 1. Souhrnné zobrazení jednotlivých kategorií

\section{Testování vztahu mezi proměnnými a faktory}

Pro ověřování hypotéz byly použity dva druhy testování v závislosti na daném faktoru. Pro faktory pohlaví, univerzita a forma studia byl použit t-test pro nezávislé vzorky dle skupin, jelikož dané faktory vždy dělí soubor na dvě skupiny. Testování t-testem bylo prováděno $\mathrm{v}$ programu STATISTICA 9.

Faktor studovaný obor pak soubor dělí na 4 různé skupiny, proto nebylo možné testování ttestem a byl použit test analýzy rozptylu (One-way ANOVA). Testování bylo prováděno za použití programu IBM SPSS Statistics.

$\mathrm{V}$ rámci testování jsou výsledky považovány za signifikantní na zvolené hladině významnosti 0,05 .

\subsection{Interpretace výsledků ze statistického testování}

V následujících odstavcích jsou shrnuty a interpretovány výsledky ze statistického testování.

Co se týče faktoru pohlaví, nebyly prokázány statisticky významné rozdíly mezi průměrnými hodnotami sebeposouzení mužů a žen v žádné kategorii. Lze tedy říci, že pohlaví nemělo vliv na to, jak respondenti posuzovali své sociální dovednosti a osobnostní kvality v žádné oblasti. $\mathrm{Na}$ základě tohoto výsledku se lze pak přiklánět k názoru, že spíše než pohlaví bude mít na sebeposouzení vliv pregraduální příprava budoucích učitelů. Jak ovšem vyplývá z předchozího textu, složení respondentů v ohledu na pohlaví bylo velmi nevyvážené, což rovněž odráží i stále značně feminizovanou pedagogickou realitu. Tento fakt mohl způsobit zkreslené výsledky testování.

Dalším faktorem, který byl testován v každé kategorii, byl studovaný obor. Zde byl shledán statisticky významný vliv faktoru pouze v rámci kategorie Pedagogická komunikace a Zvládání konfliktů. Z těchto výsledků lze tedy vyvozovat, že z pohledu studovaného oboru nedocházelo ke statisticky významným rozdílům mezi průměrnými hodnotami sebeposouzení ve zbylých kategoriích. Tento fakt si dovolujeme přisoudit tomu, že v rámci průběhu studia lze předpokládat pro jednotlivé obory shodnou nebo velmi podobnou skladbu předmětů 
týkajících se osobnostního a sociálního rozvoje studentů ${ }^{2}$ V tomto ohledu mohou být tedy zajímavé spíše výsledné průměrné hodnoty sebeposouzení v jednotlivých kategoriích.

Naopak v př́padě faktoru univerzity se jednalo o statisticky významný vliv studované univerzity na průměrné hodnoty sebeposouzení respondentů ve všech kategoriích vyjma kategorie Supervize. Navíc byly v těchto kategoriích vždy prokázány statisticky významně vyšší průměrné hodnoty sebehodnocení u respondentů Masarykovy univerzity vzhledem $\mathrm{k}$ průměrným hodnotám sebeposouzení respondentů $\mathrm{z}$ ostatních univerzit. Lze tedy usoudit, že studenti Masarykovy univerzity posuzují své sociální dovednosti a osobnostní kvality vyššími hodnotami než je tomu tak u studentů $\mathrm{z}$ ostatních univerzit.

Podobným výsledkům se dospělo při testování faktoru formy studia. Zde byl rovněž zjištěn statisticky významný vliv faktoru formy studia na průměrné hodnoty sebeposouzení respondentů ve všech oblastech vyjma kategorie Supervize. Vyšší průměrné hodnoty pak byly přisuzovány respondenty studujícími kombinovanou formu studia. Jak také vyplývá z některých volných komentářů v sebeposuzovacím dotazníku, lze u respondentů kombinované formy studia předpokládat jistou (mnohdy i několikaletou) praxi v oboru učitelství, což může výrazně ovlivnit jejich posouzení vlastních sociálních dovedností a osobnostních kvalit. $\mathrm{Z}$ těchto úsudků vyplývá také důležitá pozice praktických zkušeností studentů učitelství, jež rovněž zaznívala při expertních rozhovorech.

Zvláštní pozornost si pak také zaslouží výsledky testování v kategorii Supervize. Již z předchozích interpretací vyplývá, že v této kategorii nebyl zjištěn statisticky významný rozdíl mezi průměrnými hodnotami sebeposouzení respondentů pro žádný testovaný faktor. Lze tedy konstatovat, že na posuzování sociálních dovedností a osobnostních kvalit v oblasti supervize nemá vliv žádný z testovaných faktorů. Je však nutné podotknout, že povědomí o supervizi je v pedagogickém prostředí velmi malé, což rovněž vyplývalo z volných komentářů v sebeposuzovacím dotazníku. Neexistenci statisticky významného vlivu žádného z faktorů na tuto oblast lze tedy přisuzovat zmíněné nízké informovanosti o supervizi.

\section{Závěr}

Výsledky výzkumného šetření mohou být aplikovatelné pouze na skupinu studentů pedagogických fakult. V rámci pedagogické profese se ovšem na základních i středních školách setkáváme také $\mathrm{s}$ učiteli, kteří neabsolvovali žádný $\mathrm{z}$ učitelských oborů na pedagogické fakultě. Tento fakt není možné vyloučit a nelze tedy výsledky výzkumného šetření vztahovat na celou pedagogickou realitu, nýbrž pouze na zmíněné studenty pedagogických fakult. Nabízí se tedy možnost získat další zajímavé informace $\mathrm{v}$ prrípadných výzkumných studiích, např. porovnáním současných výsledků $\mathrm{s}$ výsledky získanými testováním právě potenciálních učitelů, kteří neabsolvovali učitelský obor na pedagogické fakultě.

Př́nos shledáváme zejména $\mathrm{v}$ uceleném pohledu na dílčí sociální dovednosti a osobnostní kvality budoucích učitelů, a to z hlediska odborného a teoretického vymezení, z hlediska posouzení vzdělavatelů na pedagogických fakultách a z hlediska vlastního posouzení potenciálních budoucích učitelů. Zajímavé výstupy se objevují zejména ve výsledcích testování vlivu faktorů na sebeposouzení respondentů, které mimo jiné potvrzují významný vliv studované univerzity či formy studia na to, jak studenti posuzují své sociální dovednosti a osobnostní kvality. Toto výzkumné šetření by pak mohlo být základem k dalšímu zkoumání

\footnotetext{
${ }^{2}$ Náplň předmětů jednotlivých oborů lze vyhledat a srovnat na základě informací z webových stránek jednotlivých univerzit: www.muni.cz, www.cuni.cz, www.upol.cz, www.uhk.cz.
} 
sociálních dovedností a osobnostních kvalit studentů jednotlivých univerzit např. formou kvalitativního šetření, které by podrobněji prozkoumalo jednotlivé kategorie. Zjištěný vliv zejména pregraduální prrípravy na posuzování sociálních dovedností a osobnostních kvalit v jednotlivých oblastech pak může být přínosnou zpětnou vazbou především pro pedagogické fakulty daných univerzit. $Z$ našeho pohledu shledáváme rezervu zejména $v$ oblasti supervize, která byla odborníky i teoretickým vymezením shledána jako potřebný a možný efektivní nástroj pro profesní a osobní růst učitelů, ovšem v pedagogickém prostředí se s ní zatím spíše nesetkáme.

\section{Literatura}

Kraus, B. (1999). Profese učitele a sociálně pedagogická činnosti. Praha: PdF UK v Praze.

Navrátilová, I. (2011). Sociální dovednosti a osobnostní kvality budoucích učitelü. (Diplomová práce). Brno: MU.

Průcha, J., Walterová, E., \& Mareš, J. (2009). Pedagogický slovník. Praha: Portál.

Valenta, J. (2008). Cesta k druhým aneb Sociálně kompetentní učitel sociálních kompetencí. In J. Kolář \& B. Lazarová (Ed.), K sobě, $k$ druhým, $k$ profesi: Teorie, programy a metody osobnostního a sociálního rozvoje pedagogických pracovnikư. Brno: MU.

\section{Kontakt}

Mgr. Petr Soják, Ph.D.

Masarykova univerzita

Pedagogická fakulta, Katedra sociální pedagogiky

Poříčí 7, 60300 Brno

e-mail: sojak@ped.muni.cz

Iva Navrátilová

V Lískách 13, 59101 Žd'ár nad Sázavou

e-mail: iwa.na@seznam.cz

\section{Bibliografické údaje}

Soják, P., \& Navrátilová, I. (2011). „Soft skills“ začínajících pedagogů aneb s jakými sociálními dovednostmi a osobnostními kvalitami odcházejí učitelé z pedagogických fakult do profesní reality. In T. Janík, P. Knecht, \& S. Šebestová (Eds.), Smíšený design v pedagogickém výzkumu: Sborník príspěvků z 19. výroční konference České asociace pedagogického výzkumu (s. 209-214). Brno: Masarykova univerzita.

Dostupné z: http://www.ped.muni.cz/capv2011/sbornikprispevku/sojaknavratilova.pdf doi: 10.5817/PdF.P210-CAPV-2012-69 